\title{
Chemical weapons as potential tools in terrorist attacks - risks and preventive action
}

\author{
Andrzej Czop ${ }^{1}$ \\ ${ }^{1}$ Pedagogical University of Cracow
}

\begin{abstract}
This publication looks at shopping malls as a specific category of public facilities. It includes a diagnosis of their safety, pointing to specific irregularities and negligence that threaten them with exposure to possible terrorist attacks. The current international situation is examined, including the crisis that arose as a result of uncontrolled mass migration, which implied an increased threat from Islamic terrorism, which Europe has not yet learned to effectively respond to. A particularly dangerous instrument that can be used by modern terrorists is the chemical weapon. We give examples of its use in acts of terror. The research indicates that a high level of security for public facilities such as large commercial outlets, which accumulate a large number of customers in their premises, is a very important issue. The use of chemical weapons in shopping malls could lead to significant loss of civilian life, as civilians would be a defenceless target. The research process carried out by the author finally drew the conclusion that the current level of security for large-format retail centres does not provide optimal protection in the event of a chemical weapon attack. Therefore, implementing the articles recommendations should positively affect the diagnosed situation and have a significant impact on the improvement of the safety standards in public buildings such as shopping malls.
\end{abstract}

Keywords: large-format retail centres, terrorist attacks, public safety, chemical weapons, combat toxic agents

* Corresponding author: kcb.aczop@o2.pl

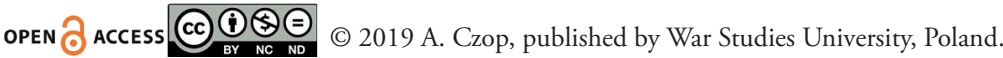

This work is licensed under the Creative Commons Attribution-NonCommercial-NoDerivatives 4.0 License. 


\section{Introduction}

When analysing the current situation in the world, it is easy to note that one of the main factors threatening international security is Islamic terrorism, which adopted a quasistate form of so-called Islamic State - "ISIS". For many years, Al Qaeda was considered the most dangerous terrorist organisation, its most spectacular success being the attack on the World Trade Centre in New York and the headquarters of the Pentagon. At that time, it seemed that we were dealing with the apogee of the Islamic extremism threat. A much more serious threat was the emergence of the self-proclaimed Islamic State with its primary goal - the global expansion of the Islamic revolution beyond the area traditionally considered as culturally and religiously bound with Islam. Hence, terrorist attacks have been inspired and carried out by this organisation in previously relatively safe countries of the European Union. It is Europe and the US that are considered the main symbols of Western culture and civilisation, which must be destroyed by terrorists in jihad (Czop, Piwowarski 2015).

\section{Factors that imply an increase in the threat of terrorism}

Over recent years, mass migration from war zones in the Middle East and Africa has been an important factor undermining security and stability in Europe. The wave of migrants coming to the EU countries, especially Germany, has become a phenomenon over which the governments of these countries and the European community have been unable to control in an effective way. Among those who escaped the nightmare of the war were also the perpetrators of it who, using the chaos that reigned, reached countries that offered hospitality and humanitarian aid to the victims (Czop, Piwowarski 2015, pp. 3844). In these countries, the seemingly already assimilated Muslim population is radically re-Islamising. This has resulted in attacks carried out by citizens of those countries who are descendants of Muslims who arrived there in the second and sometimes even the third generation. For the followers of Islam, politics is subordinated to religion entirely, often even these are considered as the same concepts. In the Muslim countries, the whole of political and social life functions on the basis of the Koran. Sharia law is the state law. In Western countries, it is difficult to imagine such subjugation of the state to religious values and order. According to K. Jałoszyński (2003, p. 115), "Contemporary 
terrorism represented by extremist Islamic fundamentalism is a war based on the clash of civilisational cultures. On the one hand, there is a whole western world dominated by the latest achievements of science and technology, functioning in the era of IT boom, on the other, millions of Muslim followers, for whom the development of civilisation stopped at the medieval level." An interesting view is presented by B. Hoffman (quoted in Jaworski 2006, p. 7) "One may ask, for example, what kind of political state the Islamic terrorists want to achieve? Most likely, their aim is to break the world domination of Christian - Jewish Western civilisation. They want to achieve this desirable political state (i.e. lack of domination) by destabilising the main countries of this civilisation, leading to an economic meltdown and social instability." It is impossible ignore that such a state situation is influenced by religious extremism, currently "reserved just for the followers of Islam" (Tomaszewska n.d.) The main goal of Islamic fundamentalists is to create a world Muslim state in which Islamic religious law will become the only law. Therefore, Muslims think that their religion must be confessed by all the inhabitants of the Earth (Sznajder n.d.). Islam divides the world dichotomously into:

- The world of Islam;

- World of war, a place where Islam is not accepted and where infidels live (Kubiak 2009, p. 17).

The presented image of the world is the cause of the constant conflict between these worlds and the calling of Muslims for "holy war" (jihad). Muslim extremists who profess religious and political fanaticism only recognise jihad as a way of achieving their goal and urge fellow believers to use "justifiable violence." So it is not fundamentalism that is the origin of terrorism, but the fanaticism that enslaved some of the fundamentalists. Only when it justifies the use of violence against followers of other religions, recognising armed struggle as the only tool, it causes Muslims to embark on a "holy war" by pursuing the "path of God". According to fanatics, peace on Earth can only happen when Islam conquers the world. However, one should not treat Islamic fundamentalism and terrorism as identical concepts.

Observing the followers of Islam who live in Europe for a long time, it can be said that the most dangerous are those who treat the smallest manifestation of their adaptation as a betrayal of their identity and rejection of basic canons and professed religious values. Recent events clearly show that the entire society of European Muslims is the object of permanent, invasive ideological influence from some Islamists living in their home countries. In the era of globalisation, modern media, communication and the possibility 
of fast travel, leveraging of such pressure is much more effective than even a few decades ago (Ostrowska 2011).

In European countries in the EU, we have seen a rapid and gradual increase in the number of followers of Islam, which is the result of a significant fertility rate, the very young demographic structure of this population and an increasing number of conversions. However, the basic reason for the constant expansion of Islamic influence is the uncontrolled wave of migrants from Muslim countries (Czop, Piwowarski 2017, pp. 30-46). Until recently, predictions of demographers assumed that this group, in the middle of the twenty-first century, would account for a quarter of Europe's population. However, the dynamic increase in the migration of the Islamist population leads to a belief that the level indicated above can be reached much earlier. Therefore, an urgent need emerges for European states to face two major challenges: to ensure the integration of the Muslim populations that already inhabit Europe and to protect their borders against uncontrolled, illegal immigration from Islamic states (Czop, Piwowarski 2017, pp. 30-46).

\section{Chemical weapons as terrorist weapons}

To face the problem, it is necessary to ask the question - does the current level of protection of large-format retail centres guarantee the safety of people using these buildings in the situation of an attack conducted by chemical weapons?

To find the answer to this fundamental question, the author raised more detailed research problems included in the questions:

- Is the chemical weapon particularly dangerous for civilians?

- Is there a real threat of attacks with chemical weapons?

- How are large-format retail centres secured against such attacks?

According to the UN Secretary-General's report on chemical and biological weapons and the consequences of their possible use, chemical weapons are combat toxic agents along with devices used to transport and apply them. The main striking element in such a weapon is a chemical compound with toxic properties. It should be noted that many types of chemical weapons use compounds that, when at room temperature, are in 
gaseous or liquid form, with high pressure, so they can be emitted into the environment by ground (stationary or mobile), or by air dispersion devices.

By chemical weapons, we consider the components that occur together or alone:

- Toxic chemicals - a chemical compound that due to its effect on living organisms may result in their death, cause periodic incapacitation or permanent injury. Substances are included, irrespective of their origin or production methods, or for their use in facilities, ammunition or elsewhere and their precursors, excluding situations where they are used for permitted purposes, if the condition of preserving their type and quantity is met, which is compatible with the accomplishment of such purposes.

- Ammunition and special equipment causing death or injuries through the toxic action of chemical compounds released as a result of the use of such ammunition and equipment.

- All special devices intended for use in connection with the use of ammunition and equipment.

It turns out that building effective and at the same time safe equipment for spraying a toxic chemical agent may be a more complex problem than the production of it. Experts express the view that it will be sufficient to use light aircraft with an installation for spraying cultivation fields to carry out a terrorist attack on cities. Chemical weapons can be produced relatively easily because there are no problems with access to technologies and necessary materials. This means that it can be used by terrorists. A lot of widely available chemicals can be easily processed or used as dangerous toxic agents. Those can be created based on public sources and recipes such as "www" websites, guides, and handbooks, with the use of ordinary laboratory equipment and / or equipment of most kitchens or gardens. As substrates for the production of chemical weapons, one can use every day available components which can be obtained in horticultural, chemical, industrial or construction shops (pesticides, herbicides, insecticides). Terrorists are well aware that the use of chemical weapons due to their operational characteristics may cause uncontrolled panic amongst the civilian population.

It is also necessary to point out to the possibility of using toxic industrial substances as a weapon of mass destruction. These substances are widely used in civil production plants (e.g. in the food industry: for example, breweries, vegetable fat plants, in the chemical industry: factories of varnishes and construction chemicals, home chemistry, etc.). Examples are: 
- Chlorine,

- Ammonia,

- Arsenic,

- Chrome,

- Carbon disulphide,

- Formalin,

- Hydrogen cyanide,

- Nitric acid.

HYDROGEN CYANIDE is very dangerous; it is produced during the burning of objects in which synthetic substances such as nylon, orlon, polyurethane are present. It is relatively easy to produce from basic substances used in industrial plants, which means that it can be used by terrorist organisations (Kubaczyk 2016, p. 33).

In 1968, an anarchist group calling themselves Meteorologists threatened to poison Lake Michigan with a hallucinogen - LSD. The lake was already a huge pool of drinking water for the inhabitants of nearby cities, but the threat itself was not real, as the perpetrators did not have the right amount of the substance (Gawliczek 2007, p. 65).

The increased interest of terrorists in chemical weapons could already be noticed in the 1970s. At that time, there was a theft of several dozen canisters containing mustard gas from the military magazines of the American army. This incident took place in 1975, and only a year later Palestinian terrorists attempted to purchase isopropyl fluorophosphates. The role of combat toxic agents was to have only an additional effect among casualties caused by conventional means - that is an explosion of a bomb (Konopski2009, p. 191).

Particularly spectacular acts of terror in which terrorists used chemical weapons included the actions of the sect of the Supreme Truth, headed by Shoko Asahara. In Japan, he is still considered one of the most dangerous extremists in the history of the country. The first attack of the sect was to spray SARIN from a container mounted on a truck. As a result of the container temperature increasing, the vapours of this gas were released and took the form of a cloud. Air currents caused its displacement over housing estates, leading to the poisoning of over 500 people, of whom 7 died. The attack took place in June 1994 in Matsumoto and, surprisingly, it was virtually unrecorded and publicised by the world's media. The Japanese authorities were not interested in publicising this event due to the fact that the police failed to capture the perpetrators of this attack. The terrorists were not identified until the autumn, when the police found a letter from an 
anonymous author, in which he warned against the next actions of the Supreme Truth sect. The sect carried out the most dangerous attack a year later. Its members sprayed SARIN inside five cars on the Tokyo Metro. The method of gas atomizsation was very primitive - it consisted in puncturing and unsealing plastic food packaging. The result of this attack was the death of 12 people, and almost 5,500 injured people were sent to hospitals. Later, the police established that the true target of the attack was not the passengers, but policemen who took measures at the metro stations to neutralise the threat. In the course of the investigation, it was revealed that the sect began attempts to produce other highly toxic substances such as TABUN, SOMAN, VX. The Group also conducted experiments using such poisonous substances as: FOSGEN, CYANIDES, and YPERITE. Although the sect had well-equipped laboratories, chemists and significant financial resources, it did not master the production technology necessary to obtain the most dangerous chemical weapons. The group also did not develop an optimal method of spraying these gases. According to experts, the use of appropriate nozzles would create opportunities for effective attacks on an unprecedented scale.

According to the intelligence information, Al - Qaeda planned to carry out attacks on the metro trains in Paris and London, duplicating the tactics used in Tokyo by the sect of the Supreme Truth. The use of chemical weapons was also planned by the Scottish National Liberation Army, whose members sent to the most important people in the British state small containers with CAPSICAL SODA, including Prime Minister Tony Blair (Konopski 2009, pp. 67-68).

Chemical weapons were also used on September 5, 2001 in San Adolfo (Colombia). Mortar shells containing unidentified gas paralysing the respiratory system were shot at the local police station. As a result of this attack, three officers were killed. Terrorists from the FARC organisation admitted the attack. When the assailants were shot, the police secured rifle ammunition containing arsenic.

According to experts, terrorist organisations focus their efforts on constructing an Improvised Explosive Device (IED) in which the chemicals, such as: CYANOGEN CHLORIDE or HYDROGEN CYANIDE could be located. According to the findings of the intelligence services, Hamas planned attacks using such toxic weapons. The assailant was to use the classic explosive to detonate and to increase the power of the attack, using a gas with highly poisonous properties. 
In March 2002, a member of Hamas tried to spray HYDROGEN CYANIDE at the Park hotel. The Iraqi Al - Qaeda group prepared an attack in 2004, during which more than 20 tons of chemicals were detonated using "IED". This explosion could have killed about 20,000 people. The operational recognition of the Jordanian security services made it possible to stop this attack. As demonstrated by investigative measures, terrorists wanted to strengthen the power of "IED" by using combat toxic agents in prepared attacks on US embassy facilities, the prime minister's office and the headquarters of Jordanian intelligence.

In Iraq in 2007, there were several assassinations in which CHLORIDE used in the technological process of treating water intended for consumption was employed. In the first four months of 2007, as a result of these attacks, dozens of people were killed and several hundred were hospitalised.

Particularly dangerous attacks may be carried out by contaminating the reservoirs of drinking water, as well as watercourses feeding such reservoirs. This type of terrorist activity can generate large losses among civilians. Preparations and attempts to attack infrastructure supplying conurbations with drinking water were recorded in the case of:

- Scandinavian pro-ecological groups

- Al-Qaeda terrorists,

- FARC militant groups

- Racist extremists in South Africa.

All the planned attacks were effectively prevented by secret services and the police (Konopski 2009, p. 71).

In addition, there have been several cases of sabotage involving food poisoning. In January 1994, food used by recruits of the Philippine police was poisoned. 19 recruits died after eating this food. Also in the same year, bottles of sparkling wine, which were sent to Russian soldiers participating in a peacekeeping operation in Tajikistan, were poisoned using cyanide. The poisoned wine caused the death of 9 soldiers and 6 civilians.

Warehouses in which large amounts of chemical substances are stored can also be targets. US intelligence services have selected 110 such facilities in New Jersey alone that if damaged would cause a gigantic ecological disaster causing pollution of the natural environment over a large area. According to experts, an attack on only 6 objects from this list would cause the death of over a million people. 
In Dallas in 1997, attackers attempted to detonate HYDROGRN SULFIDE transporting tanks at the natural gas refinery. It was a spectacular way to distract the police from the theft of an armoured car conducted at the same time.

All these events are history, but the current international situation implies a much greater threat of terrorism than it did years ago.

\section{Large-format retail centres as a potential target of a terrorist attack}

Residents of large conurbations visit large-format retail centres intended for commercial purposes, often referred to as shopping malls (Rozporządzenie Ministra Infrastruktury...). Every major city has several of them and they attract a very large number of customers. This, in turn, makes them a very attractive target for a terrorist attack. The author of the article, apart from the scientific work, has audited such buildings in order to provide the personnel and clients with appropriate security conditions. He has verified both architectural and technical safeguards as well as those resulting from the monitoring of the facility by the employees of physical protection companies. He has also determined whether the procedures applicable in such a commercial complex are correct, well understood and respected. Thus, the purpose of the audit is defined as the verification of individual areas and processes occurring on the external and internal premises of commercial facilities affecting the level of safety of people and property. Such audit, as a standard, includes verification and assessment of:

- interiors of buildings and adjacent external area,

- work and tasks of employees of physical protection companies, including checking the records of the Object Protection Manual and other instructions and procedures,

- organisation of movement of materials,

- personal traffic,

- vehicle traffic,

- protection in the field of fire safety,

- operation and deployment of CCTV system cameras.

The audit is carried out on the basis of specific methodological assumptions, which aim to achieve objective and true results. Therefore, during such examination, the author 
performed rounds and inspections of particular places, analysed available protective documentation and conducted interviews with security staff employed in a given facility.

Using the indicated research tools, the author, based on the audits he has carried out, showed the most common errors that negatively affect the safety of public facilities, especially shopping malls. Here are the most common and repeated ones, regardless of where they are located and who is in charge of their daily management.

\section{The factors lowering the security level of shopping centres}

The lack of vehicular traffic control is a weakness. This is understandable due to the commercial profile of the facility, but there is also no supervision over vehicular traffic in the Supply Zones, which obviously generates the risk of criminal situations.

Sometimes, the emergency door is not connected to the alarm system. It is often blocked in an open position by cleaning employees, which makes it easy to access for unauthorised persons. Thus, the Access Control System becomes useless and does not fulfil its role at all. There are no seals on fire hydrants and elements of fire infrastructure, the glass behind which the hydrants are located is covered with various information and advertising boards, which makes it unclear where they are located.

It happens that employees of cleaning companies block communication routes on the way to escape routes and emergency exits. Tenants of dining venues block the access to areas they occupy, which also generates the risk of unauthorised access to the area. Free access to HVAC infrastructure (heating, ventilation, air conditioning) is also a risk. This creates the possibility of unauthorised access to these important sanitary streams and, consequently, makes it easy to carry out a terrorist attack and distribute chemical substances through these installations. Access to ladders leading directly to the roofs of buildings is also easy. The number of CCTV cameras and their placement is generally unsuitable for existing needs implied by potential threats (e.g. a camera "looking at the pillar or the ceiling"). Incorrect setting of some CCTV cameras makes them practically useless and their minimal amount does not provide supervision of areas sensitive from the security point of view. Lack of proper road markings of the Delivery Zone with the sign - "Traffic Zone" and "No Stop", as well as open gates leading to these spaces create the possibility of unauthorised entry and even parking of random, unknown vehicles. 
It happens that at the entrances to security rooms, especially the Alarm Signal Monitoring Bureau, which is the security management centre, does not include videophones through which effective verification of people who want to enter these locations would be possible.

Common bad practice is that security employees do not follow procedures when issuing keys and cards to employees. Often they do not know the provisions of the Protection Manual of a given object, hence they do not know the procedures that are in force or the topography of the area. It happens that when an employee is missing to cover a security post, a person completely unaware of the specificity of the facility and the threats appearing on it is requested to take security employee duty. Sometimes, the Protection Instructions themselves are written in a cursory and vague manner that does not take into account the characteristics of a specific facility. There are even cases when such a document is a photocopy of instructions from another building and only the address or the name of the object is changed.

There are cases of complete lack of reaction from security staff to events that were the source of potential dangerous situations, e.g. the gathering of minors disturbing order or damaging equipment. Sometimes, managers or tenants of buildings explicitly forbid employees to check the identity of persons even in situations where identification would be necessary. They argue that they do not want to discourage potential customers who should only see the friendly image of the company they decided to visit. For the same reasons - "in order not to scare away customers", they prefer not to equip security personnel with direct coercion measures that are indispensable in the case of specific interventions. Surveillance of cleaning service employees is too poor. They sometimes have highly unrestricted access to many places that may be the target of terrorist activity or may facilitate such activity.

Conversations conducted with security staff revealed that many of them do not know their rights at all, including those concerning the use of weapons or direct coercion measures. Observation of the way they conduct their rounds concluded that routes are chosen in such a way that the patrol will be finished as soon as possible. It is not important whether this route is optimal or not from the real threat standpoint. Employees want to electronically confirm their presence in a given location as soon as possible without paying much attention to what is happening around and what might imply a dangerous situation. Some security staff do not have training in first aid. It is also a real problem to find a medical bag, not to mention an employee who knows 
its contents. Occasionally, security personnel are engaged by the employer to conduct activities that are completely unrelated to protection, such as: placement of advertising posters or assistance in changing the decor of shop windows. Tests to check the security's communication equipment revealed that it was not of adequate quality.

The overall remark concerns the number of mobile security guards who serve in commercial buildings. There are far too few of them in relation to the size of the structure and the personal traffic that takes place there. This was confirmed by a situation that took place on October 20, 2017 at the VIVO Gallery in Stalowa Wola. A young man, armed with two long knives, was running around the facility and stabbing random victims. At the time of the attack, there were only four security guards in the facility (Mieśnik 2017). The number of security personnel was covered by the established agreement between the shopping mall management and a security company.

The witnesses to the attack anonymously admitted that when he attacked people, the bodyguards disappeared. "There was no message or warning through megaphones" a women present in the VIVO Gallery said to TVN television at that time. "Maybe they were looking out for people who were planning to steal a candy bar" added Damian Kuziora, stabbed in the stomach. The wounded were treated by women working in the local pharmacy, not by security guards, who ought to be trained in this area.

It was a single person who attacked using the most accessible weapon - a knife. But it's easy to imagine what would happen if an attacker or attackers had used chemical weapons.

Referring to the specific problems raised in the work, the author, after conducting both theoretical and empirical research, gave the following answers:

1. Chemical weapons are particularly dangerous for the civilian population, as they do not have access to protection measures that they could use in the event of contamination. The poison gases spread very easily and can spread without any restrictions even in places which are considered seemingly safe. As shown by numerous examples, terrorists often came into possession of combat toxic agents and their use showed that it is a very effective weapon that can cause multiple victims, who usually learn about contamination when it is too late to save them. This weapon is a quiet and discreet killer.

2. There is a real threat of attacks with the use of chemical weapons because often these gases are used in technological processes and thus are available. For example: chlorine, 
which is a highly toxic substance, is used to treat water. Tanks that transport it are moving daily on our roads. Certain chemical substances (found e.g. in artificial fertilizers) can produce combat toxic agents mixed in appropriate proportions. The fact that the threat of terrorist attacks is the largest for many years is clearly visible to observers of today's political scene. The war with ISIS, the re-Islamisation of Europe and the mass, often uncontrolled migration flows, are favourable circumstances for the escalation of terrorist threats, especially those resulting from religious fanaticism. The fact that the perpetrators of the attacks have so far reached for other tools than toxic substances does not mean the real threat that those substances pose has ceased.

3. Not all public utility buildings, especially large commercial facilities, are properly protected against chemical attacks. Weaknesses pointed out in the functioning and protection of these buildings clearly indicate that they could constitute a relatively easy and attractive target of terrorist attacks. A large number of virtually defenceless people can be an incentive for terrorists.

The research also obtained an answer to the main research problem. It states the following: the current level of protection of public facilities does not guarantee the safety of people using these buildings in the case of an attack conducted with chemical weapons. This conclusion does not sound optimistic, but it is an objective assessment of the material collected during the research.

It is also necessary to emphasise that the examination of the level of security for commercial buildings was the result of the genuine concern of their owners and security companies responsible for their safety. Therefore, the comments presented in the audit report were implemented in order to increase the security status of these facilities

\section{Conclusions:}

1. According to the author, the main activity which should be systematically implemented is to precisely conduct control and audit activities in shopping malls, so it is possible to eliminate deficiencies and negative tendencies on a daily basis. Removal of those is objectively possible and does not require exceptional costs.

2. Not all of the managers dealing with managing shopping malls and their security are aware of shortcomings in the protection of these structures. Perhaps they do not 
appreciate the severity of threats and therefore do not exercise due diligence in this important area of their responsibility.

3. The research showed that it is also necessary to systematically conduct training for both security staff and employees of shopping malls, so that they know how to prevent threats and know the operating procedures when a terrorist attack occurs. In this situation, there can be no room for panic, chaos or intuitive action.

4. Currently, qualified security personnel are required to undergo training to improve their practical skills and theoretical knowledge once every five years. This frequency absolutely does not allow you to consolidate the desired habits, efficient use of weapons or direct coercion measures. The threats themselves are also evolving, so training has to be given on a regular basis, so that the reaction of security staff is adapted to these changes.

Adoption of the indicated solutions is necessary because in the era of globalisation, it is difficult to admit that Poland is a country where terrorist attacks cannot happen. To paraphrase the words of Titus Livy, Si vis pacem, para bellum (if you want peace, prepare for war). In the author's opinion, everything should be done to provide the shopping malls with an optimal level of security, and thus limit their attractiveness to potential attacks.

\section{Bibliography}

Czop A., Piwowarski J., 2015. Aktualne ruchy migracyjne jako czynnik zagrożenia terrorystycznego w Europie i w Polsce. In K. Jałoszyński, W. Zubrzycki, A. Babiński (eds) Policyjne sity specjalne $w$ Polsce, Szczytno.

Gawliczek P., 2007. Terroryzm z wykorzystaniem broni masowego rażenia (megaterroryzm) jako zagrożenie asymetryczne. Formy przeciwdziałania, Akademia Obrony Narodowej, Warszawa. Kubiak H., 2009. Przedmowa do studium. In K. Rataniec (ed.) Zachód i islam. Dylematy relacji. Kraków.

Jałoszyński K., 2003. Oblicze współczesnego terroryzmu i walka z nim w kontekście bezpieczeństwa międzynarodowego. Zeszyty Naukowe AON, 2 (5).

Jaworski M., 2006. Terroryzm - aspekty prawnomiędzynarodowe, ekonomiczne i militarne. In K. Liedel (ed.), Terroryzm. Anatomia zjawiska. Wydawnictwo Naukowe Scholar, Warszawa . Konopski L., 2009. Historia broni chemicznej, Bellona, Warszawa .

Kubaczyk T., 2016. Broń chemiczna i biologiczna we współczesnym świecie. Warszawa .

Mieśnik, M., 2017. Gdzie była ochrona podczas ataku nożownika w Stalowej Woli? Znamy odpowiedź firmy. [online] Available from: https://wiadomosci.wp.pl/gdzie-byla-ochrona- 
podczas-ataku-nozownika-w-stalowej-woli-mamy-odpowiedz-firmy-6180563343177857a [Accessed 29 Mar 2018].

Ostrowska I.J., 2011. Imigracja ludności muzułmańskiej i jej pozycja w krajach Europy zachodniej - perspektywa politologiczna. Zeszyty Naukowe Akademii Marynarki Wojennej 4 (187).

Piwowarski J., Czop A., 2017. Migracijos proceso struktura europoje ir lenkijoje ir poveikis pareigunurengimui. Public security and public order. Scientific articles, 18.

Rozporządzenie Ministra Infrastruktury w sprawie warunków technicznych jakim powinny odpowiadać budynki i ich usytuowanie z dnia 12 kwietnia 2002 r. Dz.U. Nr 75, poz. 690.

Sznajder G., n.d. Terroryzm i fundamentalizm islamski. Piętno współczesnego świata? [online] Available from: http//www.otnostrow.org.pl/pliki/rocznik/2009/14_Sznajder.pdf, [Accessed 12 Apr 2018].

Tomaszewska N., n.d. Ekstremizm religijny i jego wpływ na współczesne systemy rządów. [online] Available from: http://geopolityka.org/analizy/natalia-tomaszewska-ekstremizmreligijny-i-jego-wplyw-nawspolczesne-systemy-rzadow [Accessed 6 Apr 2018].

\section{Author:}

\section{Andrzej Czop, PhD}

Pedagogical University of Cracow

(iD) https://orcid.org/0000-0002-9621-5879 